\title{
Globalisation of Pakistan: Lessons for Politically Unstable Countries
}

\author{
Yoganandan $\mathrm{G}$ \\ Department of Management Studies, KSR College of Arts and Science \\ Tiruchengode 637 215, Tamil Nadu, India \\ E-mail: g_yoganandan@yahoo.com
}

\begin{abstract}
Pakistan was one of the founder members of World Trade Organisation (WTO) and also a founder member in its erstwhile General Agreement on Trade and Tariff (GATT) but, people in Pakistan were not much exposed to globalisation. In this article an attempt is made to identify the ways and means of implementation of globalization, to provide a holistic picture and the reasons for the failure of the globalisation process in globalization. The article is written on the basis of secondary data published in various sources. It was found that the economic liberalization has been opted not as a policy generated indigenously but largely as an obligation under the conditionalities imposed by the International Monetary Fund (IMF) and World Bank through their Structural Adjustment Programme (SAP). The Structural Adjustment Programme has been a big failure in Pakistan. The liberalization process is mainly carried out in financial sector, Trade, Legal system, Administration, agriculture, education and Health care sector. This process actually aggravated job market. It has been a sour phenomenon for young people who are looking for a job as the unemployment rate is growing. The findings suggest that the other countries with unstable political scenario should approach globalization with prudence and caution.
\end{abstract}

Keywords: Globalisation, Reform process, Privatization, Pakistan, Structural adjustment programme

\section{History of globalisation in Pakistan}

Like many other closed economies, globalisation was not a choice but a compulsion for Pakistan (officially, Islamic Republic of Pakistan). Globalisation is a process of global economic integration, which includes freedom to market forces and freedom to factors of production. In other words it's a process of creating a boundary- less world. Interdependence and interconnectedness are the basic pillars of globalisation. It eliminates all forms of trade barriers to provide an open market. But globalisation as such, shall have impact on cultural, political, legal and technological environment hence, globalisation shall be defined as a process of integration of societies of all countries in fact, it is a process towards a new economic order, a monotonous world.

Globalisation has been defined in more ways by politicians, economist and eminent scholars from different field. And, they best explain it for their own interest hence; it's one of the concepts that are understood partially by many. People in many parts of the world yet do not know even the concept particularly, people in sub-Saharan countries ruled by dictators and people who live mountain ranges of Pakistan and Asian countries. Though Pakistan was one of the founder members of World Trade Organisation (WTO), and also a founder member in its erstwhile General Agreement on Trade and Tariff (GATT), people of Pakistan were not much exposed to globalisation. The reasons for non-proliferation of awareness could be many particularly, political will, available communication infrastructure, implementation policies, literacy rate, form of government etc.

As stated earlier, Pakistan opted for open economic policies (read globalisation) by compulsion during the early 1990s. The economic liberalization has been opted not as a policy generated indigenously but largely as an obligation under the conditionalities imposed by the International Monetary Fund (IMF) and World Bank through their Structural Adjustment Programme (SAP).

The Structural Adjustment Programme has been a big failure in Pakistan. As part of this SAP, Pakistan received approximately US\$ 31 billion in the form of external assistance and International Monetary Fund loans during 1985 to 2000 but, the amount spent for improving the infrastructure and poverty reduction was very minimal. The globalisation implementation policies or the SAP suggested by the IME and the World Bank has not been well received in Pakistan but it was improper to put all the blame to the globalisation and liberalization process. Many consider that the reason for higher poverty incidence is because of poor governance, lacking up of long term political policies, poor infrastructure, higher illiteracy, corruption, poor corporate governance etc. Globalisation only aggravated the already ailing economy. 


\section{Privatization}

The effort for privatization could be traced from the early years of 1980s. But those attempts did not bring any desired results. In 1990, Pakistan tried to divest its stake in state run profit-making companies and, for that government identified six profit making companies. In this attempt government, though not fully successful, managed to divest 10 per cent stake in Pakistan International Airlines to private bidders

The privatization process got its momentum in 1991 when government announced establishing Privatization commission. The privatization commission identified 106 State Owned Enterprises (SOE) that includes business units, banks and other non-banking financial units, as prospective privatization candidate. Today all the State Owned enterprises have been privatized and, nearly Rs.60 billion were collected as proceeds of privatization.

The Mission statement of Privation commission states that

"Privatization is envisaged to foster competition, ensuring greater capital investment, competitiveness, and modernization, resulting in enhancement of employment and provision of improved quality of products and services to consumers and reduction in the fiscal deficit".

The objectives of privatization can be traced from the Mission statement. They are

1. To allow the domestic companies to face the competition.

2. Greater freedom in areas of venturing.

3. No level playing in the case of uncompetitive industries.

4. Maximum utilization of resources.

5. Access to / bring in modern technologies.

6. Creation of employment opportunities that comes by the expansion of industrial activity.

7. More revenue to the government by increased international trade.

8. Creation of infrastructure through foreign investment.

9. Emergence of new areas of business those are possible only in the open economy.

10. Finally, to the consumers, availability of quality products at competitive price. Thus, higher standards of living for the people.

\subsection{Steps involved in Privatization}

The common procedures involved in most of Privatization cases are given below.

1. Identification of entity (ies) that needs to be privatized.

2. Financial adviser is hired and the hiring process is guided by either Board approved regulations or Hiring of Financial Advisor Regulations 2001.

3. The next step is related to identification of technical and legal problems and enacting suitable rules for privatization particularly for companies formed by the Act in parliament.

4. Then the value of the company (the property) to be privatized is assessed.

5. The next step is inviting Expression of Interest (EOI) by advertisement, submission of bid and identification of suitable bidder (normally highest bidder).

Typically, it takes 18 months to complete one privatization deal. Additional time period may be required for such cases that require changes in rules and regulations. The privatization process received severe opposition from political parties and trade unions. The political gambling by politicians and the fear of losing job or at least the so-called extra benefits among employees created mayhem to the privatization process. A section of the elite and the industrialists were also against the privatization process as they were very skeptical about the benefits of privatization and worried about its ill effects during the transition period.

The policy stance of government in 1970s was nationalization. But, nationalization eroded the spirit of private entrepreneurs thus, failing to achieve its stated objective. So the government had to rethink about the nationalization process. Finally in 1977, the government introduced new policy measures in order to restore the confidence among private entrepreneurs. The new policy measures like denationalization, disinvestments and decentralization was quite contrary to the previous policy stance and had become the cornerstone of privatization process in Pakistan. 


\subsection{Chronology of Privatization process}

1977- Announcement of denationalization, disinvestments policies.

1985- Setting up of cabinet committee for disinvestments.

1988- Appointment of British Consultant firm M/s N.M.Rothschild.

1989- Report "Privatization and Public participation in Pakistan" by M/s N.M.Rothschild.

1990- Formation of Committee on Disinvestments and Deregulation (CDD).

1991- Report submitted by CDD.

1991- Formation of Privatization commission.

1992- Privatization of 69 manufacturing units and two commercial banks.

Till 2007, the privatization commission has successfully completed privatizing 165 companies and through which Rs.457.919 billion has been mobilized.

List of major transactions completed so far

a) Sale of $51 \%$ of GOP stake in HBL for Rs. 22.409 billion

b) Sale of $26 \%$ shares of PTCL for Rs. 155.000 billion

c) Sale of GOP share holding in KESC for Rs. 15.860 billion

d) Sale of shares of Pakarab Fertilizers Rs. 14.125 billion

e) Sale of shares of Pak American Fertilizers Rs. 15.949 billion

f) Sale of shares of National Refinery Ltd for Rs. 16.415 billion

g) Sale of GOP shareholding in POL, ARL and D.G Khan Cement through Stock Exchange for Rs. 5.862 billion.

h) Divestment of 30\% shares of Bank Al-Falah for Rs. 620 million.

i) Management Rights of ICP three transactions for Rs. 1.265 billion

j) Divestment of $13.2 \%$ shares of NBP for Rs. 1.386 billion

k) 5\% ordinary shares of OGDCL thru Capital Market for Rs. 6.851 billion.

1) Sale of Mustehkam Cement Limited for Rs. 3,205 million

m) $10 \%$ shares of SSGC for Rs. 1.734 billion through Capital Market

n) Sale of 5.8\% shares of PIA for Rs. 1.2 billion through Capital Market

o) Sale of $15 \%$ shares of PPL through Capital Market for Rs. 5.6 billion

p) Sale of the Falleti's Hotel, Lahore for Rs. 1.211 billion

q) $20 \%$ shares of KAPCO through Capital Market for Rs. 4.815 billion

r) $4.22 \%$ shares of UBL through Capital Market for Rs. 1.087 billion

s) Sale of Carrier Telephone Industries for Rs. 500.0 million

t) Sale of International Advertising (Pvt) Limited for Rs. 5.117 million

u) Sale of Bolan Textile Mills for Rs. 128.0 million

v) Additional shares of United Industries for Rs. 7.7 million

w) OGDCL GDR thru foreign \& local institutions for Rs. 46.963 billion

x) Sale of Javedan Cement Limited for Rs. 4,316 million

y) Sale of Lasbella Textile Mills for Rs. 156.0 million

z) Sale of Lyallpur Chemical \& Fertilizers for Rs. 280.2 million

\section{Structural Adjustment Programme (SAP)}

The liberalization or Structural Adjustment Programme (SAP) was pursued with the view to revive the economy. It has the following key elements 1). Removal of distortions in the economy 2). Enhancing the macroeconomic stability conducive for business venturing 3). Emphasizing economic governance and 4). Poverty alleviation.

It was assumed that liberalization would bring competitive spirit along with foreign money and technology, this in turn would foster strong economic growth, that would create lots of employment opportunities and thereby reduce poverty. Thus, in Pakistan policy makers thought that globalisation is the panacea for all the problems. Unfortunately, the poverty incidence was much higher in post-globalisation era. But, it seems that globalisation did not bring any unemployment. Even in the pre-globalisation years the poverty incidence and unemployment were higher in all years except a few. The few years in which the Pakistan economy grew more than 6 per cent saw fewer poor and more employment growth. Hence, it is obvious that to sustain employment rate and to 
reduce the poverty incidence, Pakistan economy (GDP) has to grow more than 6 per cent and suitable policy measures should be employed for that cause.

The liberalization process is mainly carried out in the following sectors.

1). Financial sector liberalization which includes

a). Capital market reforms

b). Foreign Exchange liberalization (Current Account convertibility and Capital

Account convertibility)

c). Banking sector reforms and non-banking financial sector reforms

d). Foreign Direct Investment reforms (FDI) and Foreign Portfolio Investment reforms.

e). It also includes prudent fiscal and money management by the central bank.

2). Trade liberalization.

a). Removal of import controls.

b). Removal of export subsidies.

c). National treatment to all companies.

d). Elimination of Import-substitution.

e). Removal of entry and exit barriers.

f). Non-discrimination of imported products.

3). Legal reforms

a). Creation of legal system conducive to business. (Nationalization to Privatization).

b). Harmonizing legal system with that of the WTO and other International Institutions (IMF, World Bank, Asian Development Bank etc).

c). Amendment of Employees Act.

d). Faster proceedings of cases and settlement.

4). Other areas of reform
a). Administrative reforms (civil and police services).
b). Agricultural sector reforms.
c). Educational sector reforms
d). Health sector reforms.
e). Miscellaneous.

\section{Capital market reforms}

The reforms in the capital market were aimed at creating a vibrant, market friendly system to provide investors a new avenue for investing and for entrepreneurs an easy way to raise money. The stock markets in Pakistan witnessed a boom immediately after the announcement of liberalization policies in 1991.A new $\mathrm{T}+3$ settlement mechanism was announced along with more prudent risk management regulations were imposed for stock exchanges.

The Securities and Exchange Commission of Pakistan (SECP) became a more powerful system regulator to deal with future needs. Other important reforms were the setting up of National Clearing and Settlement System, announcement of new code of conduct for the stockbrokers, raising net margin requirement for brokers, creation of rules against insider trading and a market friendly regulatory changes for easy take over, acquisition, merger.

The stock market operation has been so refined which can be assessed from liquidity, asset quality and similar parameters of companies. Still there are areas that need a lot of attention for effective functioning of stock market. Notable among them are

1). Risk of devaluation of home currency

2). Active trading only in limited number of companies

3). Low liquidity

4). Incentives for debt and introduction of commodity markets in major cities.

The saving rate in Pakistan remains very low at $11 \%$ of GDP and the participation in stock market is quite low which can be changed only by providing secured (well informed) platform. 


\section{Foreign exchange liberalization}

A major development happened in the foreign exchange market in 1991 when government announced a number of regulations relating to foreign exchange transactions. The new regulation allowed residents to open and maintain Foreign Currency Accounts (FCA), hold foreign currency and earn return more than other savings scheme.

Officially, Pakistan has moved into free-floating regime from managed/fixed exchange rate regime in late 1990s. But in reality the exchange rate is not allowed to float freely and this can be felt from central bank's foreign exchange market operation. The State Bank of Pakistan has steadily purchased till April 2004 and has been selling steadily thereafter.

The intervention was a need of hour as the central bank has been adapting the policy of building forex reserves for the purpose of keeping sufficient import cover. But this intervention was done in order to prevent sudden money supply in the domestic economy and also to stop artificial fluctuation arising out of speculative trade and expectation. The stability of exchange rate is vital for smooth business operation particularly in the case of Exports and Imports and Portfolio Investments.

The fluctuations in the inter-bank market has been kept low and the premium hovers around 3 to 4 per cent almost through out the year. Another achievement in reforms is the elimination of Hawala or Hundi transactions that are illegal and also equally challenging to the normal functioning of the forex market. Now, the forex market is nearly at par with any other developing country markets but it clearly lacks volume to allow it to function on demand and supply.

\section{Banking sector reforms}

The first distinct banking sector reform started in the late 1980s. In 1992, licenses were given to private bank to start operation in an effort to liberalize the banking sector. In the same year two public sector banks (Muslim Commercial bank and Allied bank of Pakistan) were privatized, a bolstering steps in the direction of liberalization.

The Strengthening of regulatory role (through new prudential regulatory rules in 1989 and 1992) of central bank (State Bank of Pakistan) and privatization of banks are important reforms happened in the banking sector. Most of the Nationalized Commercial Banks (NCB) was over-staffed; a common problem associated with most of the public sector enterprises.

Efforts were taken to reduce at least half the existing strength as they were considered "surplus". The banks earmarked more then 40 per cent of existing branches as non-profitable thus, required to be closed. The banks also aimed at reducing the Non-Performing Loans (NPL) as a measure to increase asset quality. The banking system nearly collapsed in 1996 due to poor corporate governance and mismanagement in financial transactions. The political influence on lending and loan recovery disrupted the functioning of banks particularly that of the government. The non-performing asset grew to Rs 146 billion in 1998. The situation grew still worse for Nationalized Commercial banks (NCB) had 29\% NPL to their total loan portfolio. The second phases of reforms were introduced in 1997, which was sponsored by World Bank. The NPL were reduced but the achievements not outstanding.

In order to strengthen fiscal reporting, the government of Pakistan has established Fiscal Monitoring Committees at federal and provincial levels. To review audits in the public sector enterprises ad hoc Public Accounts Committees has been created. The government continues its ride on economic reform but there are areas that require further effort either at policy level or at implementation level. Implementation of court verdicts in loan recovery, eliminating political interference in bank operations along with the sound budgeting, good procurement process, internationally accepted accounting and auditing, transparency in financial operations are a must for eliminating waste and corruption and also to achieve maximum productivity in all areas of operation.

\section{Trade liberalization}

Till 1980, Pakistan was a closed economy with high level of protection. Pakistan followed a trade regime, which discourages imports and encourages exports besides it sought for import substitution. The local economy was well protected from foreign competition particularly, from the import of foreign products. The import was discouraged with tariff and non-tariff barriers. Stringent non-tariff barriers including, outright ban, quantitative restrictions, licensing, canalizing etc were employed to control imports.

Pakistan started trade liberalization in 1980s by reducing higher tariff rates on imports especially, it was rationalized in harmony with international agreement and WTO norms. It should be noted that nearly 60 per cent 
of industrial value addition was protected by import bans and by other forms of import restrictions. In the $1980 \mathrm{~s}$ quantitative restrictions were eliminated and in the 1990s restricted list was eliminated. From 1983-84 to 1993-94, 724 items were removed from the Negative list. The Negative list contains about 60 items as on 2001-02.

The openness in Pakistan has improved only very marginally from 35.17 in 1980-81 to 36.78 in 2001-01 despite reduction in quantitative restrictions and slew of other similar measures. The reason could be the devaluation of Rs during this period in order to increase (artificial, short-term) competitiveness in the international trade. The devaluation is an artificial (and official) action, which is against market economy, and besides it reduces the earning potential of foreign money invested before the devaluation.

Pakistan has not received enough benefits from trade liberalization much to be blamed by its over dependence of a few line of products. The economy is more or less dependent on Agriculture and allied industries. The contribution of Agriculture to GDP was 26.2 per cent in 1999/2000 and moved town to 23.1 per cent in 2003/04. The share of services moved up from 51.2 per cent in 1999/2000 to 52.3 percent 2003/04. But once again the contribution came from traditional service industries like public administration and there was no increase in contribution share of commerce, finance and transport. Also, the exports have been stagnant at $\$ 8$ billion for the last few years. This implies that (commerce) export and import grow only at the rate of average economic growth rate of country obviously; the liberalization did very little to international trade. And, the new economies, the symbol of service economies, were not at all growing. Service sectors like communication, transport and finance have nearly maintained the growth rate. Hence, the indicators signal that a lot more has to be done in order to get maximum benefits from globalisation.

Looking for new export markets, identifying new areas of sourcing, adding a whole range of products in to the existing export portfolio, identifying niche products and niche markets along with improving the skills of laborers by training, awareness and education etc. On the other hand protection against imports should be brought down for a decent export expansion. The maximum tariff a rate also, has to be lowered to $30 \%$ slab; other administrative hurdles should be eliminated in order to achieve speedy export and import. This will boost a trade and the related industries' growth.

\section{Agricultural sector reform}

Pakistan's Agriculture needs to be protected to an extent as it caters to around $48 \%$ of country's employment need. The contribution of Agriculture and allied industries towards countries total exports was at $65 \%$. Just like any other developing country Pakistan too was affected by globalisation. Multi Fibre Agreement (MFA), which deals with Textiles and clothing, was one such rule in GATT that affected Pakistan the most. In fact Pakistan along with other developing countries wanted to phase out this rule early. It is quite clear MFA was in favour of developed nations by allowing them to continue protection. The developed countries used Quota and similar measures to tackle import from developing nations.

The post-quota regime looks very attractive for Pakistan but it has to face renewed competition from India, China, Thailand and Indonesia. To sustain growth in Textile exports they have to move up the value chain. Pakistan should not continue to be a raw material and semi-finished product supplier to the rest of the world. In fact the market for high end products is big enough and more profitable. But Pakistan should try to have a balanced export portfolio by increasing the share of fruits in total exports.

\section{Administrative reform}

Pakistan's public service suffers from jillion numbers of problems. The public offices are overstaffed along with the problems like not adequately skilled employees, political interference in selection process, highly paid when compared with similar types of jobs in private sector, poor morale, lack of accountability and omni-present under-the-table revenue system. The reforms in this area are not unnoticeable. The railways, the largest employer in the country, a public sector unit, reduced its staff strength by golden handshake that reduced more than 40,000 of excess staff.

\section{Conclusion}

The globalisation has brought number of changes in Pakistan. In order to cope with WTO/IMF/World Bank rules and regulations, Pakistan has taken much reform in almost all sectors of the economy. Different leaders of Pakistan have implemented the globalisation in different forms in different time intervals under different circumstances. Globalisation was implemented under the compulsion of IMF and World Bank. The Leaders (Democratic and Military) somehow accepted that this phenomenon is irreversible. But the benefits accrued from globalisation is nearly nothing. It has been a sour phenomenon for young people who are looking for a job as the 
unemployment rate is growing. The agriculture sector and trade did not show any significant performance after globalisation. Higher poverty incidences were reported during post globalisation. Health sector and Educational sector needs lot to be done to fine tune itself in coherence with the development going around.

Globalisation is not a panacea for whole-lot-of problems that Pakistan face, but to benefit from globalisation, Pakistan has to educate its people and change the attitude towards it. So far globalisation is not accepted and implemented whole-heartedly and prudently. The politically unstable countries in Africa need to understand that not only the political stability but also the political policy stability are critical for any economy that wants to integrate with rest of the world and; this is very true as far as Pakistan is concerned.

\section{References}

Article- Trade liberalization: Implications for development in Pakistan by Farzana Noshab. [Online] Available: http://www.issi.org.pk/journal/2002_files/no_4/article/4a.htm

Article: Economic reforms and macroeconomic management in Pakistan. (1999-2001) by Ishrat Husain, Governor, State Bank of Pakistan. [Online] Available: http://www.sbp.org.pk/about/speech/2002/Macroperformance.pdf

Article: Future of capital markets in Pakistan by Majid Dawood, Director, Arif Habib Securities. (November 03-09, 1997). [Online] Available: http://www.pakistaneconomist.com/database2/cover/c97-14.asp

Article: Globalisation, Structural Adjustment and Public Health in South Asia: What does it mean for international Networking in Health Research and Research training? - Zulfiqar Ahmed Bhutta.

Article: History and evolution of privatization in Pakistan by Syed Anwar-ul-Hasan Bokhari. [Online] Available: http://www.policy.hu/bokhari/History\%20and\%20Evolution\%20of\%20Privatization\%20in\%20Pak..pdf

Article: Pakistan Economy: External sector crisis by Prof. Khurshid Ahmad. [Online] Available: http://www.eldis.org/fulltext/pakistaneconomy.pdf

Article: Privatization in Pakistan by Dr.A.R.Kemal.

Article: Remittances, Trade liberalization and Poverty in Pakistan: The role excluded variables in poverty change analysis (October 2002) by Rizwana Siddiqui and A.R. Kemal [Online] Available: http://www.uoit.ca/sas/Poverty\%20and\%20Social\%20Indicators/Trade\%20LibPoverPakistan.pdf

Encyclopedia.com

IMF report: IMF Country Report No. 04/415 (December 2004): Pakistan: Selected issues and Statistical Appendix. [Online] Available: http://www.imf.org/external/pubs/ft/scr/2004/cr04415.pdf

IMF Working Paper: WP/01/138: Bank reform and bank efficiency in Pakistan by Daniel C. Hardy and Emilia Bonaccorsi di Patti. [Online] Available: http://www.uoit.ca/sas/Finance\%20and\%20Finance\%20Systems/bankreform=pakistan.pdf

Report- Impact of trade liberalization on lives and livelihood of mountain communities in the Northern Areas of Pakistan. [Online] Available: http://www.umb.no/statisk/noragric/publications/master/2005_shagufta_jeelani.pdf

Report: Pakistan's Reform Program: progress and Prospects Report (March 2001) by World Bank. [Online] Available: http://www.ciaonet.org/olj/gjia/gjia_sumfall04/gjia_sumfall04_005.pdf

Report: SBP Financial Markets review 2004 by State Bank of Pakistan (SBP). [Online] Available: http://www.sbp.org.pk/

Web site: Ministry of commerce Pakistan. [Online] Available: http:/www.commerce.gov.pk/

Web site: Privatization Commission, Government of Pakistan, Pakistan. [Online] Available: http://www.privatisation.gov.pk/

Web site: State Bank of Pakistan. [Online] Available: http://www.sbp.org.pk/

World Bank Report: Pakistan Economic Report (April7, 1999)- prepared by World Bank (Poverty reduction and economic management, South Asia region). [Online] Available: www.economics.pomona.edu/.../Economic\%20Development/Pakistan\%20Economic\%20Report.pdf 